\title{
Dr. William 'Bill’ E. Shiels II (April 2, 1954 - May 5, 2015)
}

\author{
D. Gregory Bates ${ }^{1}$
}

Received: 28 August 2015 / Accepted: 1 September 2015 /Published online: 14 September 2015

(C) Springer-Verlag Berlin Heidelberg 2015

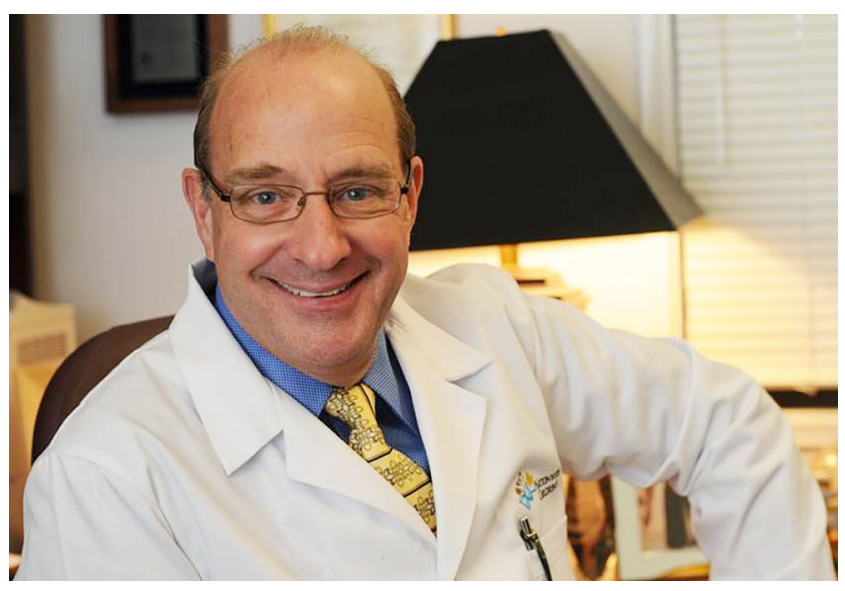

Those of us who knew him were greatly saddened by the death of Dr. William "Bill" Eugene Shiels II, who passed away at The James Cancer Hospital in Columbus, $\mathrm{OH}$, on May 5, 2015, surrounded by his loving family. Bill had recently celebrated his 61 st birthday. After his vigilant year-long battle against pancreatic cancer, we lost an extraordinary man and outstanding pediatric radiologist who left a legacy of outstanding leadership, skill and innovation, and a life filled with compassion and advocacy for the best possible medical care of children.

Bill was born and raised in Cincinnati, $\mathrm{OH}$, the 9th child in a family of 11 children, and the youngest of 4 boys. He

\section{Gregory Bates}

greg.bates@nationwidechildrens.org

1 Department of Radiology, Nationwide Children's Hospital, 700 Children's Drive, Columbus, OH 43205, USA graduated from Purcell Marion High School in Cincinnati, going on to earn a bachelor's of science and a master's degree in biology from Villanova University in 1979, and a doctor of osteopathic medicine degree from the Philadelphia College of Osteopathic Medicine in 1983.

Bill then began his distinguished military career through the Health Professions Scholarship Program with the United States Army. He was assigned to Tripler Army Medical Center in Hawaii, where he completed a transitional internship year and subsequently a diagnostic radiology residency in 1988 . Bill returned to Cincinnati on a military-sponsored exception, completing a 2-year pediatric radiology fellowship at Cincinnati Children's Hospital Medical Center in 1990. There he met two of his greatest mentors, Dr. Donald Kirks and Dr. Diane Babcock. Following graduation, Bill served as the section chief of pediatric radiology at Walter Reed Army Medical Center from 1990 to 1996 . He also acted as the radiology consultant to the U.S. Army Surgeon General from 1991 to 1995.

After fulfilling his military commitment in 1996, Bill moved to Columbus, $\mathrm{OH}$, to take over the chairmanship of the Department of Radiology at Columbus Children's Hospital, now Nationwide Children's Hospital. He devoted the next 20 years of his life building on a dream of excellence for imaging and care of pediatric patients. He did it with style, grace, commitment and an unwavering belief in himself and his colleagues. His forward-thinking and boundless optimism served him well as he continuously strived to promote the growth and development of the program.

Bill had a distinguished medical career with 60 peerreviewed publications, 20 book chapters, and more than 500 invited lectures and courses both nationally and internationally. Bill's focus on treating infants and children with vascular malformations, bone lesions, and congenital and acquired abnormalities of the head and neck was his passion. He 
pioneered successful non-surgical therapy for bone cyst and bone tumor ablation, soft-tissue foreign body removal, and percutaneous treatment of lymphatic malformations. Bill was exceptionally proud of the way foreign body interventions could be utilized in military medicine, particularly for the care of wounded soldiers. He was recently awarded a grant from the Department of Defense to train Army physicians in minimally invasive US-guided techniques for the removal of shrapnel in veterans. Bill was also well known for his research into intussusception and the development of the Shiels Intussusception Device. In addition to his exceptional clinical skills, Bill was passionate about teaching other physicians. He developed a new training paradigm for US-guided procedures with the novel use of turkey breasts for simulation that continues to attract both new and seasoned radiologists at conferences worldwide.

Bill was the recipient of a multitude of awards and recognitions, including the 2015 Society for Pediatric Radiology Pioneer Award; the 2014 Art of Medicine Award; the 2012 Golden Stethoscope award; the 2011 America's Most Compassionate Doctor; a 2011 Patients' Choice Award; the 2011 Dr. Floyd J. Trenery Memorial Medal from the American Osteopathic College of Radiology (AOCR), the highest honor bestowed to a member of the AOCR; the 2010 Rotary
International District Governor's Humanitarian Award; the John Caffey Gold Medal Award, twice, for research in childhood intussusception and for research in lymphatic malformations; and he was included numerous times on the Best Doctor List for Central Ohio and Best Doctors in America, just to name a few.

Bill's invaluable contributions to the field of pediatric radiology will benefit patients and colleagues far into the future. His leadership, creativity, passion for helping others, and endless optimism will be deeply missed. His career was one of curiosity, discovery, innovation and improvement in the imaging care of children. Bill may be most remembered for his unwavering commitment to his patients. He is quoted as saying, "To wake up every day and be allowed to share generously my God-given gifts and talents as a healing physician for children around the world is an incredibly humbling and meaningful responsibility," and he applied this enthusiasm and conscientiousness to his life's work.

The medical profession has lost a champion of innovation and an exemplar of outstanding patient care. Bill is survived by his daughters Courtney and Moira, who were undeniably the most important people in his life. He will be truly missed by all who knew him. 